\title{
“Terpasung Tak Terasa” (Melihat Eksistensi Politik Perempuan HTI)
}

\author{
Zusiana Elly Triantini \\ UIN Sunan Kalijaga Yogyakarta \\ Masnun Tahir \\ IAIN Mataram NTB,zusiana_elly@yahoo.com
}

Reformation has brought about various models of thought, including fundamentalist Islamic thoughts, one of them being Hizbut Tahrir Indonesia (HTI). HTI offers various concepts that are controversial, including the concept of khilafah as an alternative to the collapsed political and governmental systems of Indonesia. One of its controversial concepts is that of political role of women which is gender biased and combines sociological and theological domains. This paper reveals that such a bias is caused by the method of interpretation of texts, which is literal or textual, by which the texts have to be understood as it is explicitly written, not implicitly. This tends to reject other understandings that are logical and contextual, using historical interpretation.

Keywords: reformation, HTI, women, gender-biased.

\section{Pendahuluan}

ika ada pertanyaan tentang siapa sesungguhnya perempuan HTI, jawabnya mereka tak jauh beda dari perempuan-perempuan lainnya. Namun ada yang spesial dari perempuan HTI. Dari sisi simboli-sasinya, mereka identik dengan jilbab besar dan pakaian jubah yang serba tertutup, kecuali muka dan telapak tangannya. Selain itu, dari segi penampilan perempuan $\mathrm{HTI}$ akan terlihat seragam pada event-event tertentu seperti demonstrasi atau konferensi.

Sedangkan dari sisi pemikiran, perempuan $\mathrm{HTI}$ secara garis besar berpandangan bahwa "Khilafah adalah solusi dan harga mati untuk negeri ini". Oleh karena itu, bisa kita lihat di setiap event yang diadakan oleh HTI, termasuk perempuan HTI kata "Khilafah" selalu menjadi jargon yang tidak pernah ditinggalkan. Mengapa demikian? Karena ajaran organisasi yang sejatinya adalah partai politik Ideologis yang melandaskan gerakan dan ajarannya pada Islam, yang pada awalnya merupakan sebuah partai politik Islam di Palestina ini berpijak pada keharusan mengembalikan Khilafah Islamiyah dengan bertopang kepada fikrah (ide) sebagai sarana paling pokok dalam perubahan.

Kelahiran Hizbut Tahrir (selanjutnya disingkat HT) di Indonesia sesungguhnya dibidani dan dipelopori oleh beberapa orang anggota dan simpatisan HT yang telah bersentuhan langsung dengan gerakan ini di Timur Tengah. Oleh karena itu, tidak heran jika nama, bentuk, doktrin, ideologi dan metode gerakannya benar-benar mengikuti HT di Timur Tengah. Bahkan HTI merupakan cabang resmi dari jaringan HT Internasional dan bertanggungjawab kepada pengurus pusat HT di Yordania (Rahmat, 2005).

Tokoh-tokoh kunci yang - selalu disebut antara lain Syaikh Taqiyuddin Nabhani 
(1909-1979), Abdul Qadim Zallum, 'Atha Abu Rusytah (http://ms.wikipedia.org). Sedangkan tokoh dan pemimpin yang sering disebut dalam HTI antara lain Mama Abdullah Bin Nuh (2004), Muhammad al-Khaththath (Pemimpin HTI Indonesia), dan Ismail Yusanto. HTI tergolong kelompok Islam Fundamentalis karena doktrin yang mereka bangun seringkali melihat masa lalu Islam (romantisme masa lalu, tanpa memperhatikan sisi kekurangannya), dan keinginannya untuk menjadikan syari'ah sebagai pedoman bernegara. Penggolongan ini diperkuat oleh pandangan beberapa tokoh, antara lain, Musa Kailani yang mengartikan fundamentalisme sebagai gerakan sosial keagamaan yang mengajak umat Islam kembali kepada prinsip-prinsip Islam yang fundamental dan kembali kepada kemurnian etika dengan cara mengintegrasikannya secara positif (Abegebriel dan Syitaba, 2004). Kemudian Jan Hjarpe yang mengungkapkan bahwa fundamentalisme merupakan keyakinan kepada AI-Qur'an dan Sunnah sebagai dua sumber otoritatif yang mengandung norma-norma politik, ekonomi, sosial, dan kebudayaan untuk menciptakan masyarakat yang baru (2004). Dan satu lagi Leonard Binder menyatakan bahwa fundamentalisme sebagai sebuah gerakan keagamaan yang menjunjung tinggi romantisme periode Islam awal (2004).

\section{Kajian Pustaka}

\section{Pemikiran dan Peran Politik Perempuan HTI}

HTI memiliki pemikiran tersendiri tentang politik perempuan, bahkan sering menjadi kajian khusus dan penting, terbukti dengan dicetak buku khusus tentang peran politik perempuan, kemudian dirilis film tentang peran politik perempuan, dan diadakannya berbagai pertemuan (halaqah) yang membahas tentang tema politik perempuan.

Konsep dasar yang mereka miliki tentang politik perempuan adalah "dakwah sebagai peran politik perempuan". Dakwah yang dilakukan melalui berbagai cara menawarkan konsep khilafah kepada masyarakat, khususnya perempuan melalui pengajian yang diadakan di masjid-masjid. Selain itu dakwah juga dilakukan melalui media seperti booklet khusus tentang perempuan, buletin AI Wa'i, majalah AI Wa'i dan media film dokumenter yang diputar juga dalam forum-forum pengajian. Isu -isu yang banyak mereka angkat antara lain tanggapan dan pandangan mereka (organisasi) tentang kepemimpinan perempuan, jender, feminisme, HAM, dan beberapa isu yang pada saat ini telah menjadi trend global.

HTI banyak melakukan kritik terhadap terminologi-terminologi Barat. Mereka mengatakan bahwa term-term yang berasal dari Barat bertentangan dengan Islam. Beberapa kritik yang dilontarkan antara lain terhadap konsep gender dan feminisme. Menurut HTI gagasan keadilan dan kesetaraan gender atau yang sering disebut dengan KKG (Keadilan dan Kesetaraan Gender) adalah sebuah konspirasi kelanjutan dari upaya menghapuskan peradaban Islam dan mencegah kebangkitannya kembali melalui penghancuran keluargakeluarga muslim. Untuk mempertahankan hegemoninya, Barat, yang masih menaruh dendam terhadap Islam, memanfaatkan berbagai isu seperti demokrasi, HAM, pluralisme, dan KKG sendiri. Di balik opini KKG sesungguhnya tersimpan bahaya besar bagi eksistensi keluarga dan masyarakat muslim. Konspirasi keji dibalik program pemberdayaan perempuan versi KKG ini bertujuan untuk menghancurkan kepe- 


\section{Eksistensi Politik Perempuan... ; Zusiana Elly Triantini \& Masnun Tahir}

mimpinan laki-laki dalam keluarga dan masyarakat, sekaligus menghapuskan peran keibuan yang menjadi tulang punggung lahirnya generasi muslim yang berkualitas. Oleh karena itu, langkah-langkah KKG ini menurut HTI harus diwaspadai (2006).

Mereka menilai isu gender merupakan alat yang paling ampuh untuk merusak perempuan Islam. Isu KKG bukan solusi mengatasi keterpurukan perempuan, malah menambah persoalan baru yaitu perempuan merasa terhina ketika melakukan tugastugas domestik karena tidak dianggap berkontribusi untuk ekonomi bangsa, karena tidak menghasilkan income. Inilah yang membuat perempuan-perempuan meninggalkan tugas domestiknya, yang oleh Allah telah dibuat seharmonis mungkin, yang pada akhirnya institusi rumah tangga rusak dan generasi hancur.

Selain mengkritik terminologi KKG, HTI juga berpendapat, bahwa feminisme telah membawa banyak perubahan di belahan bumi mana pun. Banyaknya kaum perempuan yang telah berhasil mengekspresikan diri, bekerja di bidang apapun yang diinginkannya, tanpa harus takut dengan berbagai hal tabu yang selama ini dianggap mengekang mereka merupakan salah satu bukti menurut HTI. Bahkan hal ini dianggap sebagai awal persoalannya karena selain membawa dampak postif, feminisme juga membawa dampak buruk bagi masyarakat secara keseluruhan. Kebebasan yang ditawarkan feminisme bagi HTI berakibat pada runtuhnya struktur keluarga, meningkatnya angka perceraian, merebaknya free-sex, meningkatnya kasus aborsi, dilema perempuan karir, sindrom cinderella complex, pelecehan seksual, anak-anak bermasalah, dan lain-lain. Walhasil yang terbentuk bukan masyarakat yang kokoh, tetapi sebuah masyakat yang penuh dengan konflik yang tidak mem- berikan ketenangan dan kepastian, karena berbagai penyimpangan banyak terjadi di dalamnya (2005).

Beberapa kritik HTI terhadap feminisme antara lain: pertama, ketidakadilan gender yang dikatakan telah melembaga secara universal dalam struktur masyarakat patriarkhis sesungguhnya terbantah oleh realitas bahwa berbagai fakta yang disebutsebut sebagai persoalan perempuan ternyata juga dialami oleh kaum laki-laki. Bahkan di dunia ketiga yang mayoritas negeri kaum muslim, persoalan-persoalan seperti kemiskinan, diskriminasi, kekerasan, kebodohan, malnutrisi dan sebagainya kini menjadi persoalan-persoalan krusial yang dihadapai masyarakat secara keseluruhan sebagai implikasi dari penerapan sistem kapitalisme yang lemah dan rusak, dengan sistem politiknya yang bobrok, sistem sosialnya yang rapuh, dan sebagainya (2003).

Kedua, ide kesetaraan jender yang diusung feminisme merupakan gagasan yang absurd, ambivalen dan utopis, sebab sebagaimana sudah dijelaskan, kaum feminis meyakini, bahwa sifat keperempuanan yang dianggap lebih banyak merugikan perempuan bukan merupakan bentukan yang alami (nature/kodrati) melainkan dibentuk oleh kebudayaan (nurture). Untuk itu mereka menuntut adanya perubahan konstruksi sosial budaya baik secara kultural maupun struktural. Dengan begitu diharapkan pembagian peran yang berspektif gender tidak ada lagi. Dalam hal ini mereka yakin, bahwa ketika suatu saat masyarakat bisa memandang perempuan sebagai manusia (bukan atas dasar gender), pembagian peran domestik vis a vis publik pun akan cair dengan sendirinya. Artinya semua orang akan mampu berkiprah dalam bidang apapun yang diinginkannya tanpa 
harus khawatir dianggap menyalahi kodrat dan sebagainya.

Ketiga, cara pandang feminisme yang individualistik dan cenderung emosional juga telah menempatkan persoalan perempuan seolah terpisah dari persoalan masyarakat secara keseluruhan. Hal ini terkait dengan pandangan demokrasi yang menganggap, bahwa masyarakat adalah kumpulan individu-individu yang merdeka, dengan lakilaki di satu sisi dan perempuan di sisi yang lain. Dengan demikian, di dalam demokrasi prinsip individualisme menjadi sesuatu yang inheren. Prinsip ini telah menempatkan diri, ego, jenis dan kelompok sebagai sumber orientasi. Ketika muncul persoalan-persoalan yang menyangkut komunitas perempuan, mereka lantas memandang persoalan tersebut sebagai urusan internal komunitas perempuan. Akibatnya, pemecahan yang dimunculkannya pun hanya dilihat dari satu perspektif saja, yakni perspektif perempuan. Padahal realitasnya, masyarakat bukan hanya sekadar terbentuk dari individu-individu saja, tetapi juga dari kesamaan pemikiran, perasaan, dan aturan yang diterapkan, yang disertai dengan adanya interaksi terus menerus (2003).

Keempat, politik dalam perspektif feminisme seolah terbatasi pada aspek kekuasaan dan legislasi saja. Akibatnya ide, pemberdayaan peran politik perempuan pun selalu diarahkan untuk menjadikan kaum perempuan mampu melibatkan diri dan berkiprah seluas-luasnya di wilayah politik formal; seperti di lembaga-lembaga pemerintahan atau kekuasaan, lembaga legislasi, partai politik, dan lain-lain. Hal ini sebetulnya terkait dengan logika feministik yang diilhami oleh teori mekanisme kekuasaan mayoritas yang ada dalam logika demokrasi yang menganggap apabila perempuan terlibat dalam kebijakan, maka masalah perempuan akan terselesaikan. Padahal, dalam tataran praktik, masalah ada tidaknya hubungan antara kiprah politik perempuan seperti itu dan tuntasnya persoalan perempuan masih sangat debatable. Banyak fakta justru menunjukkan bahwa keberadaan perempuan di parlemen atau di puncak kekuasaan sekali pun tidak lantas menjamin tuntasnya persoalan-persoalan perempuan. HTI mencontohkan kasus Indonesia yang pernah kepala negaranya perempuan, ternyata 'nasib' perempuan tidak lebih baik daripada nasib perempuan yang ada di negeri yang kepala negaranya seorang laki-laki. Demikian juga realitas keterpurukan yang terjadi Banglades ketika dipimpin oleh Begum Khalida Zia dan Sheikh Hasina Wajed (2003).

Bagi $\mathrm{HTI}$ yang terpenting dalam hal ini adalah bukan masalah kuantitas perempuan yang berkiprah di wilayah politik, melainkan kembali pada ideologi yang benar dan seragam dalam konteks politik yang didasari oleh akidah yang benar, yaitu akidah Islam dengan penerapan hukum-hukumnya.

Kelima, anggapan bahwa demokrasi merupakan jalan terbaik bagi penyelesaian persoalan-persoalan perempuan sehingga mereka harus ikut memperjuangkannya adalah anggapan yang sangat lemah. Sebab demokrasi dan demokratisasi sendiri, baik dari segi teori maupun praktiknya, banyak sekali mengandung ambivalensi (Abdillah, 1999). Gagasan kedaulatan ditangan rakyat sehingga rakyat berhak menentukan hukum (prinsip mayoritas), selalu melahirkan tirani minoritas, karena kehendak rakyat yang mayoritas sering harus tunduk kepada kehendak wakil rakyat yang minoritas. Jika demikian faktanya, bagaimana mungkin kita bisa berharap sistem ini bisa memberikan kebaikan pada 'nasib perempuan', apalagi pada manusia secara keseluruhan (Sa'idah \& Khotimah, 2003). 


\section{Eksistensi Politik Perempuan... ; Zusiana Elly Triantini \& Masnun Tahir}

Menurut HTI kritik atas feminisme jelas tidak boleh berhenti pada tataran teoritis atau praktis saja, mengingat jika dilihat dari sudut pandang Islam keberadaan ide ini sangat berbahaya karena terkait dengan halhal prinsip yang menyangkut tatanan akidah maupun syari'ah. Salah satu yang paling urgen adalah mengkritisi sejauh mana keabsahan gagasan rekonstruksi figh perempuan dengan metodologi tafsir feminis yang digunakannya, seberapa layak pula gagasan-gagasan 'kaum pembaharu' bisa diadopsi sebagai landasan beramal bagi kaum muslim maupun muslimah dalam menjalani peran dan fungsi sosial yang akan dipertanggungjawabkan di akherat kelak (Sa'idah \& Khotimah, 2003).

Lebih lanjut HTI menilai, bahwa pemikiran para tokoh feminis ini sangatlah rancau dan berbahaya, dan inilah yang perlu diwaspadai oleh umat Islam karena: Pertama, ide ini merupakan produk pemikiran barat yang menganut faham liberalis dan kapitalistik; kedua, faham ini tegak di atas landasan pemisahan agama dari kehidupan, akibatnya menafikan khalik dalam mengatur kehidupan, ketiga; keberadaan gerakan-gerakan ini telah mengkondisikan kaum muslim untuk menyetujui ide-ide yang ditawarkan, sekaligus menjadi pengembannya walaupun akan mengikis kesempurnaan Islam; keempat, seperti penjelasan sebelumnya bahwa ide ini telah memunculkan ketimpangan dan keguncangan struktur masyarakat dan keluarga; kelima, ide ini makin menjauhkan kaum muslim dari gambaran keagungan dan keunikan masyarakat Islam dengan aturan sosialnya yang manusiawi, sekaligus memadamkan cita-cita mereka untuk hidup di dalam masyarakat Islam. Malah ide-ide yang diusung feminisme kian mendekatkan kaum muslim pada hukum-hukum barat yang rusak dan merusak. Padahal seha- rusnya disadari bahwa secara politis, negara kapitalis yang menjadi sponsor dan suporter gerakan feminis ini sangat berkepentingan dengan ide-ide seperti ini di dunia Islam (Sa'idah \& Khotimah, 2003).

Pemikiran HTI ini didasari oleh pandangan mereka yang menganggap semua mabda atau ideologi selain Islam seperti kapitalisme, sosialisme, komunisme, nasionalisme, patriotisme, free masonry, sektarianisme dan isme-isme sejenis tidak lain sebagai ideologi (mabda) yang rusak dan bertentangan dengan fitrah manusia. Mabda-mabda tersebut merupakan buatan manusia selain rusak dan cacat, semuanya bertentangan dengan Islam dan hukum-hukum Islam. Mengambilnya, menyebarluaskannya, dan berkelompok berasaskan mabda-mabda tersebut termasuk perkaran yang diharamkan Islam. Kaum muslim juga diharamkan mendirikan partai politik berdasarkan ideologi-ideologi buatan manusia tersebut, juga haram menjadi anggota dan simpatisannya, karena partai-partai politik seperti itu termasuk partai-partai kufur dan mengajak kepada kekufuran (Nashir,2007).

Hal lain yang juga menjadi bidikan wacana HTI dalam hal peran politik perempuan adalah soal Pemimpin Negara Perempuan. Menurut HTI di antara aktivitas politik tertentu yang tidak diperkenankan oleh Allah untuk digeluti perempuan, yakni aktivitasaktivitas yang termasuk dalam wilayah kekuasaan atau pemerintahan. Dalam hal ini, yang dimaksud dengan wilayah kekuasaan atau pemerintahan adalah wilayah pengaturan urusan umat yang dilakukan secara langsung dan menyeluruh, misalnya menjadi penguasa. Penguasa dipandang sebagai orang yang bertanggungjawab penuh secara langsung dan menyeluruh dalam mengurus urusan umat. Dalam sistem Islam, jabatan pengu-asa mencakup 
khalifah (kepala negara), muawin tafwid (pembantu khalifah dalam urusan pemerintahan), wali (kepala wilayah), dan amir (kepala daerah) (Sa'idah \& Khotimah, 2003). Oleh karena itu, tidak heran pada tahun 2004 menjelang pemilihan presiden (pilpres) sekitar ribuan massa HTI Sulawesi Selatan (Sulsel) melakukan unjuk rasa. Salah satu pernyataan sikapnya yakni menolak kepala negara perempuan. Hal yang sama juga pernah mereka lakukan pada masa kepemimpinan Megawati.

Dengan istilah lain, menurut HTI Islam telah mengharamkan jabatan kekuasaan bagi perempuan dan mengkhususkannya bagi laki-laki. Hanya saja pengkhususan ini bukan untuk merendahkan atau menjadikan perempuan sebagai warga negara kelas dua, karena Islam memandang bahwa peran penguasa dan rakyat dalam politik sama pentingnya. Penguasa adalah pelaksana politik yang bersumber dari hukum-hukum Allah, sedangkan rakyat berperan sebagai pengawas dan pengoreksi kehidupan politik berdasarkan hukum-hukum Allah (Sa'idah \& Khotimah, 2003).

Dalam konteks ini jabatan kepala negara merupakan sebuah tanggung jawab yang besar, karena menyangkut terlaksananya pengaturan kehidupan umat sesuai dengan aturan Allah dan Rasul-Nya sehingga Islam memberikan aturan yang rinci tentang masalah ini. Syaikh Taqiyuddin an-Nabbhani (pendiri HT), dalam kitabnya Nizam al-Hukmi fi al-Islam, sebagaimana dikutip Najmah Sa'idah, menegaskan syarat-syarat utama seorang kepala negara, yaitu:

1. Muslim, berdasarkan firman Allah dalam Surat An Nisa (4): 141.

2. Laki-laki, berdasarkan hadits Nabi lanyufliha qaumun walluu amrahum imra'atan.

3. Balig.

4. Berakal sehat.
5. Adil, artinya konsisten dalam menjalankan agamanya, berdasarkan firman Allah dalam Qur'an Surat Ath-Thalaq (65): 2.

6. Merdeka, karena seorang budak tidak memiliki wewenang untuk mengatur dirinya apalagi mengatur orang lain.

7. Mampu melaksanakan tugas kekhalifahan, yaitu mampu memelihara urusan umat.

Berdasarkan syarat-syarat yang dikemukakan oleh pendiri HT tersebut, menurut HTI syarat laki-laki sebagai kepala negara dan pejabat penguasa dibawahnya adalah syarat mutlak bagi pemerintahan Islam. Hal ini telah menjadi sunnah Rasulullah dan dipegang teguh oleh kaum muslim dari masa ke masa. Para ulama mujtahid empat mazhab bahkan telah bersepakat, bahwa mengangkat seorang perempuan menjabat kepala negara adalah haram.

Ragam pemikiran HTI tentang perempuan di atas dipengaruhi oleh cara pandang tekstualis atau literal yang digunakan oleh HTI. Hasil pemikiran tekstualis ini tentu akan menghadirkan pemahaman yang sempit tentang perempuan karena kebanyakan pemikir Islam kontemporer mengatakan bahwa pemikiran-pemikiran yang dangkal dan sempit tentang Islam biasanya lahir dari cara pandang atau penafsiran yang tekstualis. Oleh karena itu, untuk memperluas cara pandang $\mathrm{HTI}$ dan menyingkirkan belenggu di tubuh HTI terhadap perempuannya, penulis sebagai outsider menganggap perlu melakukan kritik terhadap pemikiran $\mathrm{HTI}$ agar terwujud ruang-ruang keadilan bagi perempuan $\mathrm{HTI}$.

\section{Kritik atas Pemikiran HTI}

Ada beberapa kritik yang hendak penulis sampaikan terhadap pemikiranpemikiran HTI. Tentang konsep gender (KKG) misalnya, menurut penulis tidak 


\section{Eksistensi Politik Perempuan... ; Zusiana Elly Triantini \& Masnun Tahir}

seharusnya HTI mencurigai atau mewaspadai konsep KKG ini,sebab KKG merupakan salah satu gerakan yang muncul untuk memperjuangkan keadilan dan kesetaraan bagi perempuan, sebuah citacita yang sejalan dengan pesan dasar ajaran Islam.

Kesetaraan dan keadilan gender adalah suatu kondisi yang mencerminkan adanya kedudukan yang setara antara laki-laki dan perempuan dalam keluarga, masyarakat, berbangsa, dan bernegara. Term ini muncul untuk memperjuagkan agar perempuan memperoleh hak-haknya sebagai manusia sehingga mampu berperan dan berpartisipasi dalam berbagai kegiatan politik, ekonomi, sosial, budaya, pendidikan dan keamanan serta kesamaan dalam menikmati hasil pembangunan. Sedangkan keadilan jender adalah kondisi dan perlakuan yang adil bagi perempuan dan laki-laki.

Semangat keadilan dan persamaan (tanpa diskriminasi) merupakan salah satu tema pokok (al-maudu' al-asasiyah) dan pesan universal yang banyak disitir dalam al-Qur'an. Salah satu ayatnya adalah dalam surat al-Taubah (9) ayat 71. Dalam ayat ini diterangkan bahwa antara laki-laki dan perempuan memiliki hak dan kesempatan yang sama dalam berpolitik. Sebagaimana laki-laki, perempuan juga memiliki hak mengatur masyarakat umum (wilayah al'am). Mereka memiliki hak yang sama untuk memerintahkan yang ma'uf dan mencegah yang munkar.

Begitu juga dalam riwayat yang sangat terkenal mengenai sahabat Umar bin Khattab dan seorang perempuan yang menyanggahnya. Suatu ketika Umar berkhotbah di masjid dan mengimbau agar tidak memberikan mahar tinggi kepada perempuan.Khutbah Umar tersebut sekonyong-konyong mendapat tanggapan dari seorang perempuan yang menyatakan bahwa dia pernah mendengar firman Allah: "Dan jika kamu ingin mengganti isterimu dengan isteri yang lain, sedang kamu Telah memberikan kepada seseorang di antara mereka harta yang banyak, Maka janganlah kamu mengambil kembali dari padanya barang sedikitpun. apakah kamu akan mengambilnya kembali dengan jalan tuduhan yang dusta dan dengan (menanggung) dosa yang nyata?" (QS.4:20). Setelah dibacakan ayat tersebut Umar mengatakan, bahwa pernyataan perempuan tadi yang benar dan penda-patnya yang salah. Riwayat ini dianggap sebagai bentuk persetujuan dan sikap akomodatif Umar terhadap peranan perempuan dalam wilayah publik, artinya seorang perempuan dibenarkan oleh Islam turut serta dalam mengurus umat dan terlibat dalam urusan politik praktis (Hasyim,2001).

Sedangkan dalam pemikirannya tentang feminisme penolakan HTI terhadap isme-isme, termasuk feminisme di atas lebih terlihat sebagai gerakan politik anti Barat, padahal apabila ditilik dari lahir dan berkembangnya isme-isme tersebut tidak terlepas dari gerakan perubahan yang cukup besar, dan banyak isme yang ditolak oleh $\mathrm{HTI}$ pada realitanya diterima dengan baik di berbagai belahan dunia, seperti nasionalisme dan demokrasi, sehingga kalau HTI menyatakan bahwa di balik isme-isme tersebut tersimpan bahaya dan konspirasi besar dari Barat, menurut penulis terlalu berlebihan. Akan tetapi kalau dikatakan, bahwa Barat menjadi salah satu peradaban yang membesarkan isme-isme tersebut, alasan itu masih bisa diterima. Dan jika HTI mengatakan bahwa isme-isme tersebut merupakan paham yang tidak bebas nilai, maka HTI harus memiliki jawaban yang cukup kuat untuk mengatakan bahwa HTI bebas nilai, karena tidak ada suatu paham dan pemikiran yang bisa dikatakan bebas 
nilai, apalagi penafsiran-penafsiran terhadap teks. Atas dasar ini, barangkali, signifikansi pembedaan antara produk penafsiran dengan sumber penafsiran, antara penafsiran atas penafsiran dengan penafsiran langsung terhadap sumbernya perlu dilakukan. Al-Qur'an dan al-Sunah itulah sumber penafsiran, sementara yang selainnya adalah hasil penafsiran yang kemungkinan bias dengan realitas sosial budaya, politik, dan nuansa psikis saat penafsiran itu diturunkan. Kondisi seperti inilah yang disebut prior text. ${ }^{28}$

Rentetan pemikiran yang menolak gender dan feminisme adalah menolak kepemimpinan perempuan, tentu karena wacana kepemimpinan perempuan erat kaitannya dengan gender dan gerakan feminisme. Seperti halnya pemikiran kepemimpinan perempuan yang dikeluarkan oleh HTI. Penolakan kepemimpinan perempuan biasanya disandarkan pada hadits "lan yufliha qaumun walluu amrahum imra'atan". Hadis ini seringkali dipahami secara literal untuk menghukumi perempuan tidak layak atau tidak diperbolehkan menjadi pemimpin tanpa memperhatikan berbagai konteks yang melingkupi kondisi masyarakat pada saat hadits tersebut diturunkan. Padahal untuk mengetahui keabsahan pengambilan hukum tersebut, perlu dilihat asbab al-wurud al-hadis (sebab-sebab munculnya hadits). Ahmad ibn Ali ibn Hajar al-'Asqalani (w.852 $\mathrm{H})$ dalam karyanya Fathul Barimenegaskan bahwa hadis tersebut bermula dari kisah Abdullah ibn Hudzafah, kurir Rasulullah saw yang menyampaikan surat ajakan masuk Islam kepada Kisro Anusyirwan, penguasa Persia yang beragama Majusi. Anusyran menanggapi sinis ajakan tersebut dengan merobek-robek surat. Nabi Saw memiliki firasat bahwa Imperium Persia kelak akan terpecah belah sebagaimana Anusyirwan merobek-robek surat tersebut. Tak berapa lama, firasat itu terjadi, akhirnya kerajaan dipimpin putri Kisro yang bernama Buran. Mendengar realitas negeri Persia yang dipimpin perempuan, Nabi Saw berkata: "lan yufliha qaumun walluu amrahum imra'atan". Komentar Nabi ini sangat argumentatif, karena kapabilitas Buran yang lemah di bidang kepemimpinan. Melihat latar belakang ini, turunnya hadis tersebut tampak kasuitis dan kondisional. Objek pembicaraan Nabi bukanlah kepada seluruh perempuan, tetapi hanya tetuju kepada putri Anusyirwan yang kredebilitas kepemimpinannya sangat diragukan. Terlebih di tengah percaturan politik Timur Tengah saat itu yang rawan peperangan antar suku. Hadits ini juga bukan berupa kalimat larangan (nahiy), tetapi hanya khabariah (berita). Oleh karena itu, hukum haram (larangan) pun tidak memiliki signifikansi yang akurat. Quraish Shihab menambahkan bahwa hadis ini khusus ditujukan kepada masyarakat Persia dan tidak kepada masyarakat umum dan dalam semua urusan Shihab, 1998).

Komentar Nabi tersebut, dalam analisa Said Aqiel, sangat argumentatif, karena kapabilitas Buran yang lemah di bidang kepemimpinan. Obyek pembicaraan Nabi bukanlah kepada seluruh perempuan, akan tetapi hanya tertuju kepada Ratu Buran, puteri Anusyirwan yang kredibilitas kepemimpinannya sangat diragukan. Terlebih ditengah percaturan politik Timur Tengah saat itu yang rawan peperangan antar suku (Siraj, 1999).

Dari aspek substansi nash, hadis tersebut juga bukan berupa kalimat larangan (nahiy), tapi hanya khabariah (berita). Karena itu, hukum haram (larangan) terhadap pemimpin atau kepemimpinan perempuan menjadi tidak memiliki signifikansi yang akurat. Tidak berlebihan jika 


\section{Eksistensi Politik Perempuan... ; Zusiana Elly Triantini \& Masnun Tahir}

kemudian Ibn Jarir Al-Thabari menandaskan, pemimpin (presiden) perempuan bukanlah mani' (penghalang) dalam hukum Islam. Pendapat ini kemudian dikuatkan pula oleh sebagian ulama Malikiyyah dalam memberikan legitimasi Ratu Syajaratud Dur di Mesir (Siraj, 1999).

Dilihat dari aspek dalil, hadits ini tidak cukup syarat dijadikan pelarangan keterlibatan perempuan menjadi pemimpin. Karena menurut ushul fiqh, sebuah nash, baru dapat dikatakan menunjukkan larangan (pengharaman) jika memuat setidaknya halhal berikut. Pertama, secara redaksional, nash dengan tegas mengatakan haram. Kedua, nash dengan tegas melarangnya dalam bentuk nahi. Ketiga, nas diiringi oleh ancaman (uqubah). Keempat, menggunakan redaksi lain yang menurut gramatika bahasa arab menunjukkan tuntutan yang harus dilaksanakan. Adapun redaksi hadis lan yufliha qaumun tersebut tidak bisa diarahkan pada pelarangan (haram) (Jalil, 2000).

Secara kontekstual, posisi perempuan yang ditempatkan sebagai subordinat lakilaki sesungguhnya muncul dan lahir dari sebuah bangunan masyarakat atau peradaban yang dikuasai laki-laki, yang secara populer dikenal sebagai peradaban patriarkhi. Pada masyarakat seperti ini, perempuan tidak diberikan kesempatan untuk mengaktualisasikan dirinya dan berperan dalam posisi-posisi yang menen-tukan. Oleh karena itu, laki-laki diposisikan lebih superior daripada perempuan.

Penulis melihat pemahaman HTI tentang ketidakbolehan perempuan menjadi pemimpin terlihat tekstual dan konservatif sehingga sangat bias gender. Apabila pemahaman ini dihadapkan pada fakta-fakta sejarah yang ada maka ia akan terbantahkan. Sejumlah perempuan terbukti telah mampu memimpin bangsanya dengan sukses gemilang. Pada masa sebelum Islam, dikenal Ratu Balqis -penguasa negeri Saba-yang diceritakan al-Qur'an. Kepemimpinannya dikenal sukses gemilang dan negaranya aman sentosa. Kesuksesan Balqis ini antara lain disebabkan karena ia mampu mengatur negaranya dengan sikap dan pandangan yang demokratis. Selain Ratu Balqis, di era modern ini banyak sekali perempuan yang juga relatif sukses memipin bangsanya sendiri seperi: Indira Gandi, Margaret Tatcher, Benazir Buto, dan lain-lain. Sebaliknya terdapat sejumlah besar kepala negaranya berjenis kelamin laki-laki yang gagal memimpin bangsanya. Sejak tahun 2000-an sejumlah negara dikepalai atau dipimpin oleh perempuan. Antara lain Bangladesh, Guyana, Irlandia, Selandia baru, Sri Langka, Jerman, Indonesia dan beberapa negara di Eropa.

Kegagalan dan kesuksesan memimpin suatu negara dengan demikian tidak ada kaitan sama sekali dengan persoalan jenis kelamin, tetapi lebih pada sistem yang diterapkan dan kemampuan memimpin. Penulis ingat ungkapan Ibnu al-Qayyim alJauziyah -sebagaimana dikutip Husein Muhammad- bahwa persoalan-persoalan yang menyangkut kemasyarakatan dan politik, yang paling penting adalah kemaslahatan (Muhammad,2001).

Terkait dengan pemikiran beberapa ulama yang mengajukan syarat laki-laki bagi seorang pemimpin penulis berpendapat bahwa pemikiran ulama tersebut sudah tidak relevan dengan konteks zaman dan harus mengalami peninjauan ulang agar hukum Islam tetap eksis dan shalih li kulli makan wa zaman (kontekstual dalam segala ruang dan waktu).

Selain itu, jika dipahami lebih teliti, hadis lan yufliha tersebut tidak secara tegas melarang seorang perempuan menjadi pemimpin. Jika asumsinya adalah karena perempuan tidak memiliki kemampuan rasio 
yang memadai jika diperhadapkan dengan laki-laki seperti argumentasi yang biasa digunakan untuk menolak kepemimpinan perempuan, maka alasan yang demikian bisa dipahami ketika pada masa-masa dahulu, kondisinya memang miskin akses informasi, dan menjadikan perempuan tidak bisa mengetahui suatu persoalan secara komprehensif. Hal ini tidaklah mengherankan, jika kemudian perempuan pada abad pertengahan -ketika banyak sekali kitab figh dikarang-perempuan terpinggirkan secara sosial-politik sehingga mereka tidak bisa mengakses pendidikan, informasi dan pengetahuan (Jalil, 2004).

Dengan situasi zaman yang seperti sekarang ini, yang diiringi telah begitu terbukanya seluruh aspek yang dulu tidak bisa diakses perempuan, maka asumsi di atas menjadi terpatahkan secara otomatis. Selain itu, asumsi perempuan secara fisik juga lemah sehingga tidak pantas menjadi pemimpin, juga menjadi tidak signifikan lagi ketika saat ini moda transportasi, komunikasi dan teknologi telah menjembatani keterbatasan-keterbatasan yang dialami perempuan.

Perjuangan politik perempuan HTI bukan karena landasan kesetaraan melainkan berdasarkan pandangan bahwa perempuanpun memiliki kewajinan besar untuk berpolitik Dalam konsepsi doktrin gerakan politik HTI, keterlibatan perempuan dalam aktivitas politik digolongkan menjadi dua yaitu aktivitas politik yang dibolehkan atau diwajibkan dan yang dilarang.

- Aktivitas politik perempuan yang dibolehkan dalam konsep HTI:

1. Hak dan kewajiban bai'at (Hamim, 2004).

2. Hak memilih dan dipilih menjadi anggota majelis umat (Sa'idah \& Khotimah, 2003).
3. Kewajiban amar makruf nahi munkar (Rahmat,2006).

4. Kewajiban menasihati dan mengoreksi penguasa (Zullum, 2002).

5. Kewajiban menjadi anggota partai (Sa'idah \& Khotimah, 2003).

Realitas sejarah dalam lintasan sejarah ditemukan keterlibatan kaum perempuan dalam aktivitas politik sudah ada sejak masa-masa awal perkembangan Islam, mereka membantu perjuangan Nabi dan sahabatnya sampai pada aktivitas yang paling berisiko seperti jihad. Realitas sejarah ini harus dijadikan argumentasi oleh HTI untuk mengizinkan perempuan terlibat dalam ranah politik secara utuh(Halim, 1997). Kalau HTI konsisten dengan jargon khilafah sebagai icon perjuangannya, maka semua sisi positif dan negatif (kelam) dari perjalanan kekhilafahan dalam sejarah peradaban Islam harus dijadikan pelajaran (ibrah). Bagaimanapun konsep Khilafah pada sejarah Islam yang selama ini dianggap sebagai abad keemasan pun memiliki sisi kelam sebagaimana diungkapkan oleh Farag Fouda. HTI seharusnya juga belajar tentang sejarah bagaimana pergulatan politik terjadi begitu keras pada masa pemerintahan Khulafaur Rasyidin. Pada masa Abu bakar misalnya terjadi penyerangan atau bahkan pembunuhan terhadap para orang yang tidak membayar zakat kepada Khalifah atau Baitul Mal. Padahal orang yang boleh dibunuh dikarenakan tiga alasan, pertama, berzina setelah berumahtangga, murtad setelah beriman, atau diqishas karena melakukan pembunuhan dengan alasan yang tidak dibenarkan (Fouda,2003). Kebijakan Abu bakar ini merupakan kebijakan politik pada saat itu yang juga kontroversial, Abu Bakar mendapatkan penentangan dari Umar, meski dalam perjalanannnya Abu bakar tetap mengejar orang-orang yang tidak membayar 


\section{Eksistensi Politik Perempuan... ; Zusiana Elly Triantini \& Masnun Tahir}

zakat.

Dari pengamatan dan pembacaan yang penulis lakukan di atas, secara hermeneutis penulis melihat terdapat keterkaitan erat antara persepsi HTI dan latar weltanschauung mereka. Latar yang dimaksud menunjuk pada prasangka, kondisi historis (liistorical situatednes), dan tradisi HTI. Secara langsung maupun tidak, anasir hermeneutik itu mewarnai horison HTI dalam menderivasi pesan tekstual ajaran Islam seputar relasi gender. Jadi pemahaman HTI itu tidak berawal dari kekosongan dalam situasi budaya yang vakum, melainkan muncul sebagai refleksi langsung dari gugusan pengalaman panjang pengetahuan dan kehidupan mereka. Persepsi HTI mengenai kesadaran gender, termasuk kepemimpinan perempuan secara langsung berkaitan dengan teks-teks doktrinal Islam yang cenderung membenci perempuan (misoginis). Akan tetapi penulis melihat bahwa hal itu tidak hanya karena Islam hadir di tengah masyarakat bertradisi "man is the best and the first" melainkan juga berlangsungnya kesimpangsiuran dalam memahami otoritas teks di satu sisi, dan dimensi penafsiran di sisi lain yang acap kali bermuara pada reproduksi wacana yang bertentangan dengan nilai kesetaraan gender. Agaknya itu memang konsekuensi logis dimenangkannya otoritas tradisi Islam demi memelihara idealitas Islam sebagai agama samawi. Trend paradigmatik "mensubordinasi konteks atas teks" menjadi fenomena umum dan nyaris dalam keseluruhan dinamika keilmuan Islam pasca abad pertengahan Hijriyah yang berimbas pada banyaknya ajaran Islam kehilangan konteks sosialnya (sekaligus relevansi sosialnya).

Setelah menganalisa peran politik perempuan HTI di pembahasan sebelumnya, penulis melihat tawaran $\mathrm{HTI}$ tersebut mengindikasikan ketimpangan antara hak yang diberikan kepada perempuan dengan beban kewajiban peran politik (dakwah) yang mereka emban untuk perjuangan partai. Perempuan sebagai anggota partai memiliki kewajiban yang sama dengan laki-laki, sedangkan dalam dataran hak perempuan HTI memiliki wilayah yang sangat terbatas, bahkan untuk menjadi anggota majelis umat pun perempuan harus memiliki kriteria khusus termasuk dari sisi umur (usia yang tidak lagi memiliki tanggung jawab besar terhadap pengasuhan anak). Pada level organisasi perempuan hanya berhak untuk mengeluarkan pendapat yang berkaitan dengan masalah umat, bagaimanapun lakilaki yang terhimpun dari majelis umat yang memiliki hak lebih untuk menentukan. Bahkan beberapa hal yang menjadi keputusan Amir pusat HT tidak harus dipertanyakan namun harus dilaksanakan, termasuk keputusan yang berkaitan dengan perempuan.

Bisa dibayangkan begitu banyak peran yang harus dimiliki oleh perempuan HTI dalam ranah publik dan domestik, namun sangat disayangkan peran ini tidak diimbangi dengan pemberian hak yang seimbang dalam ranah publik, khususnya dalam ranah politik. Mengapa hal ini tidak mendapatkan protes dari perempuan HTI? Semua itu karena doktrin yang mereka miliki telah menjadi keyakinan yang kuat.

Menurut penulis kalau HTI konsisten dengan doktrin kembali kepada al-Qur'an dan al-Hadits seharusnya memberikan ruang yang bebas bagi kaum perempuannya. Terkait partisipasi publik terutama urusan sosial politik, penulis banyak menjumpai literatur yang mengenalkan keuletan Khadijah dalam memainkan peran-peran bisnisnya, kecerdasan dan intelektualitas Aisyah sampai pernah memimpin kelompok oposisi pada zaman pemerintahan Ali bin Abi Thalib atas ketidaksetujuannya terhadap 
kebijakan pemerintah Ali pada masa itu, kemudian Ummu Salamah yang memiliki peran cemerlang dalam bidang politik. Kesemuanya ini merupakan gambaran dari kebebasan ruang sosial politik yang diberikan kepada perempuan pada masa itu.

Kalau kita mau bersikap arif sebenarnya keterlibatan perempuan di ranah publik (terlebih sebagai pemimpin) merupakan cerminan implementasi pengakuan dan penghormatan Islam terhadap perempuan. Pemberian kesempatan untuk terlibat dalam urusan publik akan memberi manfaat besar bagi terciptanya keadilan dan kesejahteraan bagi semua orang. Kehadiran pemimpin yang diharapkan mampu merumuskan kebijakan-kebijakan negara yang dapat memberdayakan berjuta-juta kaumnya dan menghapus kultur diskriminatif seharusnya tidak dibatasi dari sisi gender melainkan pada sisi kemampuan. Perilaku diskriminatif tersebut akan luntur jika konstruksi sosial yang menghargai laki-laki dan perempuan terbentuk secara seimbang. Akan tetapi, butuh perjuangan yang panjang untuk mewujudkan keseimbangan tersebut, apalagi jika melihat doktrin gerakan seperti $\mathrm{HTI}$ yang masih terkungkung pada teks verbatin nash.

Di sinilah penulis melihat keterpasungan atau bahkan hegemoni yang dilakukan oleh HTI terhadap perempuannya. Kalau hegemoni dikatakan sebagai penguasaan kelompok dominan yang digunakan untuk membentuk kesadaran sub ordinat, maka hegemoni dalam tubuh HTI tercipta antara laki-laki sebagai kelompok dominan untuk melakukan sub ordinat terhadap perempuan.

Hegemoni HTI ini dilakukan lewat pemahaman dan penafsiran yang tekstual terhadap doktrin keagamaan yang mestinya bisa ditafsirkan sesuai dengan semangat zaman, apalagi pesan dasar dari al-Qur'an sangat jelas yaitu tidak ada pembedaan antara laki-laki dan perempuan termasuk dalam politik. Apalagi jika dilihat dari latar belakang pendidikan perempuan HTI yang tergolong menengah ke atas (sebagian besar menempuh pendidikan hingga perguruan tinggi).

Apabila dilihat dalam peta pergerakan perempuannya HTI saat ini berada pada tingkatan pengakuan terhadap kemampuan dan kompetensi perempuannya dalam berpolitik, namun belum mencapai tahapan memunculkan partisipasi perempuan secara langsung dalam politik. Padahal aktivitas sosial-politik kaum perempuan mustahil dapat tercapai dengan baik tanpa merealisasikan tiga tahapan penting yang saling berkaitan, yaitu pertama, pengakuan terhadap kemampuan dan kompetensi politik kaum perempuan; kedua, penghargaan atau pengakuan tersebut mencapai momentumnya ketika kaum perempuan menjadi sadar secara politik dan menyadari tanggung jawabnya dalam masyarakat; dan, ketiga, memunculkan partisipasi politik yang luas dikalangan kaum perempuan yang dikondisikan oleh kemampuan-kemampuan dan tingkat kesadaran diri mereka sendiri yang dipraktekkan pada sebuah latar belakang sosial yang menyenangkan serta memberikan rangsangan dan momentum bagi mereka.

\section{Penutup}

Pada dasarnya, hak-hak politik perempuan dalam perspektif wacana kontemporer masih berada dalam titik perdebatan walaupun di sana-sini sudah ada perubahan persepsi. Namun, dalam pandangan penulis, informasi yang terdapat dalam alQur'an dan hadis tentang peran politik perempuan adalah memungkinkan dan tidak 
Eksistensi Politik Perempuan... ; Zusiana Elly Triantini \& Masnun Tahir

ada nas yang melarangnya. Pemahaman yang komprehensif dan menyeluruh perlu dilakukan untuk mendapatkan maqasid asysyari'ah yang ada dalam nas. Oleh, karena itu pemahaman al-Qur'an dan hadis hendaknya dilakukan secara kontekstual dengan melihat bagaimana setting sosial dan realitas yang melingkupinya.

Akhirnya, menurut penulis kalau HTI konsisten dengan doktrin kembali kepada al-Qur'an dan al-Hadits seharusnya memberikan ruang yang bebas bagi kaum perempuannya. Terkait partisipasi publik terutama urusan sosial politik, penulis banyak menjumpai literature yang mengenalkan Khadijah dalam memainkan peranperan bisnisnya, kecerdasan dan intelektualitas Aisyah sampai pernah memimpin kelompok oposisi pada zaman pemerintahan Ali bin Abi Thalib atas ketidaksetujuannya terhadap kebijakan pemerintah Ali pada masa itu, kemudian Ummu Salamah yang memiliki peran cemerlang dalam bidang politik. Kesemuanya ini merupakan gambaran dari kebebasan ruang sosial politik yang diberikan kepada perempuan pada masa itu.

\section{Daftar Pustaka}

Abdul Halim Abu Syuqqah,1997. Kebebasan Wanita, terj. Chairul Halim, Jakarta: Gema Insani Press .

Abdul Jalil, dkk.,2000. Fiqh Rakyat; Pertautan Fiqh Dengan Kekuasaan, Yogyakarta; LKiS.

Abdul Qadim Zalluum,2002. Sistem Pemerintahan Islam, terj. M.Maghfur W, Bangil: Al-Izzah.

Abu Abdillah Muhammad ibn Ismail alBukhari,t.t. Sahih al-Bukhari, Beirut: Dar al-Fikr.
Abu Daud Sulaiman, t.t.Sunan Abi Dawud, Beirut: Dar al-Fikr.

Ahmad ibn Ali ibn Hajar al-'Asqalani,t.t. Fathul Bari Syarhu Sahih al-Bukhori, Beirut: Dar al-Fikr.

Al-Wa'ie Media Politik Dakwah, No.75 Tahun VII, 1-30 November 2006.

Al-Wa'ie Media Politik Dakwah, No.64 Tahun V, 1-28 Februari 2005.

Charles Kurzman (ed.),2001. Wacana Islam Liberal; Pemikiran Islam Kontemporer tentang Isu-Isu Global, terj. Bahrul Ulum dan Heri Junaidi, Jakarta: Paramadina.

Farag Fouda,2003. Kebenaran Yang Hilang, Sisi Kelam Praktik Politik dan Kekuasaan dalam Sejarah Kaum Muslim, Penj. Novriantoni, Jakarta: Dian Rakyat.

Gatra Edisi Khusus Nomor 1-2 tahun XI. 27 November 2004

Haedar Nashir,2007. Gerakan Islam Syari'at Reproduksi Salafiyah Ideologis di Indonesia, Jakarta: PSAP

Hamim Ilyas dkk,2005. Perempuan Tertindas? Kajian Hadits-hadits Misoginis, Yogyakarta: elSaq Press \& PSW.

Hans George Gadamer, 1975.Truth and Method, New York, Seabury Press.

Hussein Muhammad,2001. Fiqih Perempuan: Refleksi Kiai atas Wacana Agama dan Gender, Yogyakarta : 
UNISIA, Vol. XXXII No. 71 Juni 2009

\section{LKiS.}

Jalaluddin Rahmat,2006. Islam dan Pluralisme; Akhlak Al-Qur'an Menyikapi Perbedaan, Jakarta: Serambi.

Masykuri Abdillah,1999. Demokrasi Di Persimpangan Makna, Yogyakarta: Tiara Wacana.

M. Imadadun Rahmat,2005. Arus Baru Islam Radikal;Transmisi Revivalisme Islam Timur Tengah ke Indonesia, Jakarta: Erlangga.

M. Quraish Shihab,1419 H/1998 M Wawasan Al- Qur an, Bandung: Mizan.

Najmah Sa'idah \& Husnul Khotimah,2003. Revisi Politik Perempuan Bercermin Pada Shahabiyat, Jakarta: IdeA Pustaka Utama.
Nasaruddin Umar, 1999. Argumen Kesetaraan Jender, Jakarta: Paramadina.

Said Aqiel Siradj, 1999. Islam Kebangsaan; Fiqh Demokratik Kaum Santri, editor: Jauhar Hatta Hasan, Jakarta: Pustaka Ciganjur.

Syafiq Hasyim,2001. Hal-hal Yang Tak Terpikirkan Tentang Isu-Isu Keperempuanan Dalam Islam, Bandung: Mizan.

Thoha Hamim,2004. Islam \& NU di bawah Tekanan Problematika Kontemporer, Surabaya: Diantama.

Ummu Nayla, 2007."Pemberdayaan Perempuan Perspektif Islam Sebuah Solusi" dalam Aliansi Penulis Pro Syari'ah, Keadilan dan Kesetaraan Gender. 